\title{
Direct Evidence for the Instability and Deactivation of Mixed-Oxide Systems: Influence of Surface Segregation and Subsurface Diffusion
}

\author{
Emre Emmez, ${ }^{\dagger}$ Evgeny I. Vovk, ${ }^{+, \neq}$Valerii I. Bukhtiyarov, ${ }^{\ddagger}$ and Emrah Ozensoy, ${ }^{*+}$ \\ ${ }^{\dagger}$ Chemistry Department, Bilkent University, 06800 Bilkent, Ankara, Turkey \\ ${ }^{\ddagger}$ Boreskov Institute of Catalysis, 630090 Novosibirsk, Russian Federation
}

\begin{abstract}
:

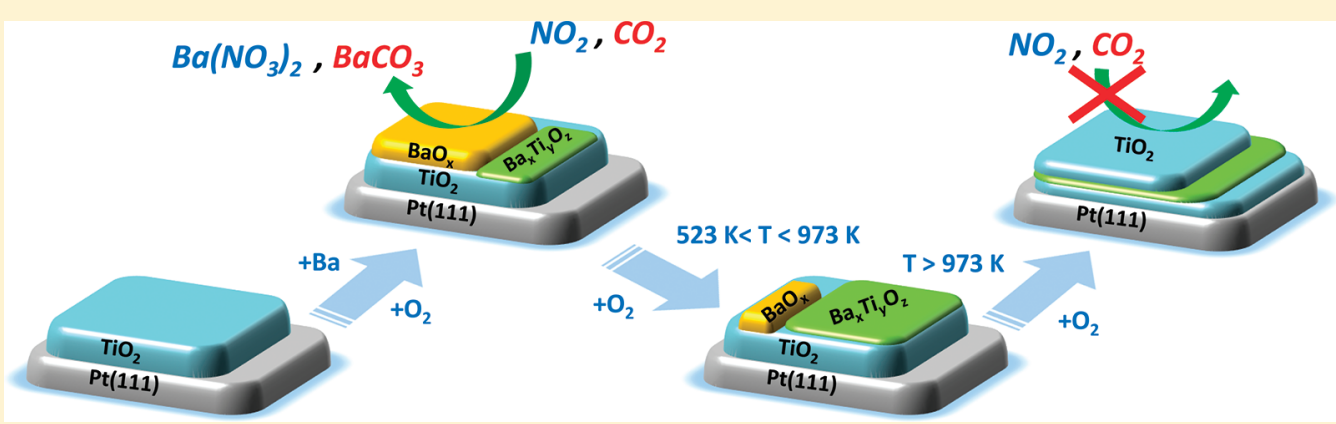

In the current contribution, we provide a direct demonstration of the thermally induced surface structural transformations of an alkaline-earth oxide/transition metal oxide interface that is detrimental to the essential catalytic functionality of such mixed-oxide systems toward particular reactants. The $\mathrm{BaO}_{x} / \mathrm{TiO}_{2} / \mathrm{Pt}(111)$ surface was chosen as a model interfacial system where the enrichment of the surface elemental composition with $\mathrm{Ti}$ atoms and the facile diffusion of $\mathrm{Ba}$ atoms into the underlying $\mathrm{TiO}_{2}$ matrix within $523-873 \mathrm{~K}$ leads to the formation of perovskite type surface species $\left(\mathrm{BaTiO}_{3} / \mathrm{Ba}_{2} \mathrm{TiO}_{4} / \mathrm{Ba}_{x} \mathrm{Ti}_{y} \mathrm{O}_{z}\right)$. At elevated temperatures $(T>973 \mathrm{~K})$, excessive surface segregation of $\mathrm{Ti}$ atoms results in an exclusively $\mathrm{TiO}_{2} / \mathrm{TiO}_{x}$-terminated surface which is almost free of $\mathrm{Ba}$ species. Although the freshly prepared $\mathrm{BaO}_{x} / \mathrm{TiO}_{2} / \mathrm{Pt}(111)$ surface can strongly adsorb ubiquitous catalytic adsorbates such as $\mathrm{NO}_{2}$ and $\mathrm{CO}_{2}$, a thermally deactivated surface at $T>973 \mathrm{~K}$ practically loses all of its $\mathrm{NO}_{2} / \mathrm{CO}_{2}$ adsorption capacity due to the deficiency of surface $\mathrm{BaO}_{x}$ domains.
\end{abstract}

\section{INTRODUCTION}

A molecular-level understanding of the fundamental interactions between different metal-oxide domains coexisting on surfaces is crucial in order to improve the performance of functional materials and to design new systems with unprecedented capabilities that can be used in electronics, sensor applications, high temperature superconductivity, energy conversion, fuel cells, photovoltaics, and heterogeneous catalysis. ${ }^{1-5}$ Alkaline-earth oxide/transition metal oxide interfaces play a central role in most of these applications where understanding and controlling the surface structure and the surface transformations seems to be the ultimate challenge for improving the state of the art in such systems. Along these lines, in the current work, we have focused our attention on a representative model alkaline-earth oxide/transition metal oxide interface (i.e., $\mathrm{BaO}_{x} / \mathrm{TiO}_{2} / \mathrm{Pt}(111)$ ) and investigated fundamental thermally induced surface structural changes by presenting a direct demonstration of the thermal catalytic deactivation of these mixedoxide systems due to subsurface diffusion and surface segregation phenomena. Although the implications of the demonstrated surface transformations are currently discussed in the context of heterogeneous catalysis, significant ramifications of the observed results can be certainly envisaged in a large number of applications exploiting analogous families of mixed-oxide interfaces.

\section{EXPERIMENTAL SECTION}

All experiments were performed in a custom-made ultra high vacuum (UHV) chamber with a base pressure of $2 \times 10^{-10}$ Torr. The UHV chamber is equipped with X-ray photoelectron spectroscopy (XPS), rear-view low energy electron diffraction (LEED), and temperature programmed desorption (TPD) techniques. XPS spectra were recorded using a Riber cylindrical mirror analyzer and a nonmonochromated $\mathrm{X}$-ray source using $\mathrm{Al}$ $\mathrm{K} \alpha \mathrm{X}$-ray irradiation $(h v=1486.6 \mathrm{eV}, 300 \mathrm{~W})$. A Dycor DM200 $\mathrm{M}$ quadrupole mass spectrometer (QMS) was used for the TPD experiments. A Pt(111) single crystal $(10 \mathrm{~mm}$ diameter, $2 \mathrm{~mm}$ thickness, both sides atomically polished, MaTeck $\mathrm{GmbH}$ ) was used as the substrate in the current studies. The $\mathrm{Pt}(111)$ single crystal was mounted on a tantalum wire assembled to a highprecision manipulator. The heating of the sample was achieved by direct resistive heating of the sample. The sample temperature was monitored by a K-Type thermocouple spot-welded onto the lateral edge of the crystal. The $\mathrm{Pt}(111)$ surface was cleaned by multiple cycles of $\mathrm{Ar}^{+}$sputtering at $1.5 \mathrm{kV}$ and subsequent

Received: July 21, 2011

Revised: September 30, 2011

Published: October 10, 2011 


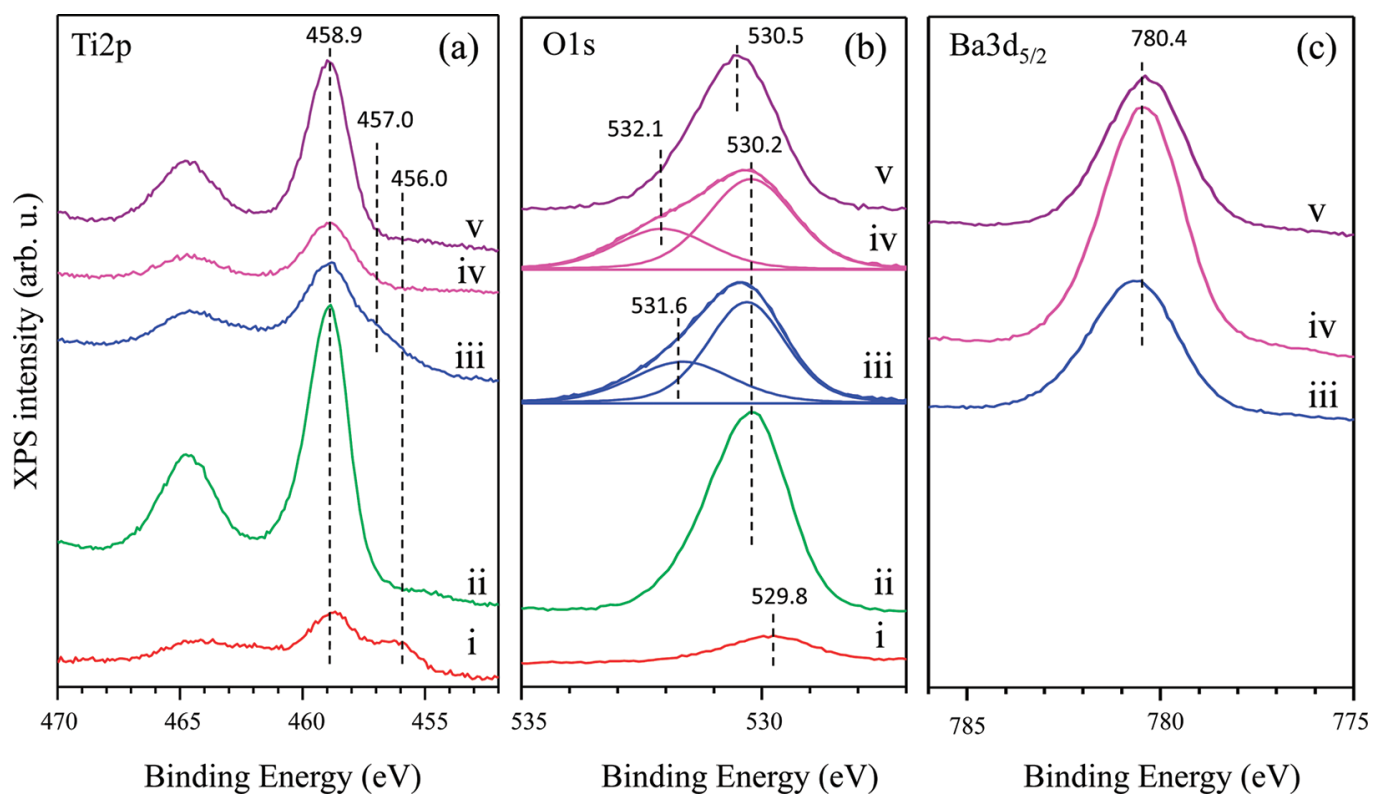

Figure 1. XPS data corresponding to the (a) Ti2p, (b) O1s, and (c) $\mathrm{Ba}_{5 / 2}$ regions obtained for (i) $\mathrm{TiO}_{x}(1.4 \mathrm{MLE}) / \mathrm{Pt}(111)$, (ii) $\mathrm{TiO} \mathrm{O}_{2}(26 \mathrm{MLE}) /$ $\mathrm{Pt}(111)$, (iii) as deposited $\mathrm{Ba}(3 \mathrm{MLE}) / \mathrm{TiO}_{2}(26 \mathrm{MLE}) / \mathrm{Pt}(111)$ surface prior to oxidation, (iv) $\mathrm{BaO}_{x}(6 \mathrm{MLE}) / \mathrm{TiO} \mathrm{C}_{2}(26 \mathrm{MLE}) / \mathrm{Pt}(111)$ surface obtained after oxidizing the sample (iii) in $\mathrm{O}_{2}\left(P_{\mathrm{O}_{2}}=5 \times 10^{-7}\right.$ Torr) at $523 \mathrm{~K}$ followed by a second Ba deposition at $\mathrm{RT}$ and oxidation at $523 \mathrm{~K}$, and (v) a surface prepared by the oxidation of sample (iv) in $\mathrm{O}_{2}\left(P_{\mathrm{O}_{2}}=5 \times 10^{-7}\right.$ Torr $)$ at $973 \mathrm{~K}$.

heating to $1073 \mathrm{~K}$ in vacuum. The cleanness of the surface was confirmed by XPS and LEED.

$\mathrm{TiO}_{2}$ films on $\mathrm{Pt}(111)$ were grown by thermal evaporation using a $\mathrm{Ti}$ wire $(99.6 \%$ purity, Mateck $\mathrm{GmbH}$ ) on a clean $\mathrm{Pt}(111)$ surface at room temperature in vacuum and subsequent oxidation in $5 \times 10^{-7}$ Torr of $\mathrm{O}_{2}$ (99.999\% purity, Linde AG) at $973 \mathrm{~K} . \mathrm{TiO}_{2}$ film thickness was estimated via the attenuation of the $\mathrm{Pt}_{4 \mathrm{f}_{7 / 2}}$ XPS signal using the equation ${ }^{6}$

$$
d_{\mathrm{ox}}=\lambda \sin \theta \ln \left[\left(\left(I_{\mathrm{Pt}}^{\infty}-I_{\mathrm{Pt}}\right) / I_{\mathrm{Pt}}\right)+1\right]
$$

where $\lambda$ is the inelastic mean free path of the $\mathrm{Pt}_{4} \mathrm{f}_{7 / 2}$ photoelectrons in the oxide film determined via QUASES-IMFP-TPP2M Ver 2.2 software $^{7}(2.7 \mathrm{~nm}), \theta$ is the take off angle between the surface plane and the outgoing photoelectrons (i.e., $48^{\circ}$ ), $I_{\mathrm{Pt}}^{\infty}$ is the intensity of the $\mathrm{Pt}_{4 \mathrm{f}}$ /2 signal for a clean $\mathrm{Pt}(111)$ surface, and $I_{\mathrm{Pt}}$ is the intensity of the $\mathrm{Pt}_{4} \mathrm{f}_{7 / 2}$ signal for the $\mathrm{TiO}_{2} / \mathrm{Pt}(111)$ surface.

$\mathrm{BaO}_{x}$ layers on $\mathrm{TiO}_{2} / \mathrm{Pt}(111)$ were prepared by thermal evaporation of $\mathrm{Ba}$ from a $\mathrm{BaAl}_{4}$ alloy (ST2/FR wire, SAES Getters) at room temperature and subsequent oxidation in $5 \times$ $10^{-7}$ Torr $\mathrm{O}_{2}$ at $523 \mathrm{~K} . \mathrm{BaO}$ coverages on the $\mathrm{TiO}_{2} / \mathrm{Pt}(111)$ were estimated using two independent ways in order to crosscheck the calculated coverage values. In the first method, $\mathrm{BaO}$ film thickness on $\mathrm{TiO}_{2} / \mathrm{Pt}(111)$ was calculated via eq 1 , where the attenuation of the $\mathrm{Ti} 2 \mathrm{p}_{3 / 2}$ signal was used instead of $\mathrm{Pt} 4 \mathrm{f}_{7 / 2}$. In the second method, $\mathrm{BaO}$ thickness was estimated by calibrating the dosing rate of the $\mathrm{Ba}$ doser on the clean $\mathrm{Pt}(111)$ surface and then calculating the $\mathrm{Ba}$ approximate coverage on the $\mathrm{TiO}_{2} /$ $\mathrm{Pt}(111)$ surface based on the Ba dosing duration and the Ba doser heating current (c.a. 10.0 A). $\mathrm{BaO}$ film thickness values obtained by these two independent methods were in good agreement with each other (i.e., with a difference of less than $25 \%$ ).

In order to estimate the coverage of $\mathrm{TiO}_{2}$ overlayers in terms of monolayer equivalents (MLE) from the calculated film thickness $\left(d_{\text {ox }}\right.$ in eq 1$)$, the ML thickness of $\mathrm{TiO}_{2}$ was taken to be
$0.325 \mathrm{~nm}$, corresponding to interlayer spacing in the $\langle 110\rangle$ direction in the bulk rutile $\mathrm{TiO}_{2}$ crystal. For $\mathrm{BaO}$ coverage calculations, the ML thicknesses were taken to be $0.39 \mathrm{~nm}$, corresponding to the interlayer spacing in the $\langle 110\rangle$ direction in the bulk $\mathrm{BaO}$ crystal. The rutile (110) surface parameters were used in the calculations since this surface is probably one of the most thoroughly investigated titania surfaces in the literature with welldefined parameters, whereas the $\mathrm{BaO}(110)$ surface parameters were used since this surface was observed to form on the $\mathrm{Pt}(111)$ surface in our recent studies. ${ }^{8}$ For reference, $1 \mathrm{ML}$ of $\mathrm{TiO}_{2}$ rutile (110) surface corresponds to $1.04 \times 10^{15} \mathrm{Ti}$ atoms $/ \mathrm{cm}^{2}, 1 \mathrm{ML}$ of $\mathrm{BaO}(110)$ surface corresponds to $0.47 \times 10^{15} \mathrm{Ba}$ atoms $/ \mathrm{cm}^{2}$, and $1 \mathrm{ML}$ of $\mathrm{Pt}(111)$ corresponds to $1.5 \times 10^{15}$ atoms $/ \mathrm{cm}^{2}$.

$\mathrm{NO}_{2}$ gas, used in the experiments, was synthesized by the reaction of NO (99.9\% purity, Air Products) with $\mathrm{O}_{2}$ and further purification by subsequent freeze-thaw-pump cycles. $\mathrm{CO}_{2}$ gas (Linde AG, Purity 99,999\%) was used without further purification.

\section{RESULTS AND DISCUSSION}

Figure 1 presents the XPS data obtained during the growth of the $\mathrm{TiO}_{2} / \mathrm{Pt}(111)$ and $\mathrm{BaO}_{x} / \mathrm{TiO}_{2} / \mathrm{Pt}(111)$ surfaces. Figure 1a (spectrum i) demonstrates that during the initial stages of the $\mathrm{TiO}_{x}$ film growth $\mathrm{Ti}$ sites are partially oxidized, which is evident from the existence of both $\mathrm{Ti}^{4+}(458.9 \mathrm{eV})$ and $\mathrm{Ti}^{3+}(456.0 \mathrm{eV})$ Ti2 $\mathrm{p}_{3 / 2}$ signals, whereas a fully oxidized thick (c.a. 26 MLE) $\mathrm{TiO}_{2}$ film (Figure la, spectrum ii) reveals exclusively $\mathrm{Ti}^{4+}$ signal. Evaporation of metallic $\mathrm{Ba}$ (3 MLE) on the $\mathrm{TiO}_{2} / \mathrm{Pt}(111)$ surface at room temperature (RT) clearly induces a partial reduction of the titania film and the formation of reduced $\mathrm{Ti} 2 \mathrm{p}_{3 / 2}$ states within the range of $457.0-456.0 \mathrm{eV}$ (Figure 1a, spectrum iii). After the oxidation of the Ba overlayer in $\mathrm{O}_{2}\left(P_{\mathrm{O}_{2}}=\right.$ $5 \times 10^{-7}$ Torr) at $523 \mathrm{~K}$ followed by a second $\mathrm{Ba}$ deposition and oxidation step at $523 \mathrm{~K}$ (resulting in a Ba coverage of ca. 6 MLE) (Figure 1a, spectrum iv), almost all of the Ti sites are oxidized to $\mathrm{Ti}^{4+}$, whereas the intensities of all of the Ti2 $\mathrm{p}$ signal visibly 
decreases. On the other hand, a further oxidation step (Figure 1a, spectrum v) at $973 \mathrm{~K}$ in $\mathrm{O}_{2}\left(P_{\mathrm{O}_{2}}=5 \times 10^{-7}\right.$ Torr $)$ drastically increases the intensities of the Ti2p signals revealing a spectrum with a close resemblance to that of a fully oxidized thick $\mathrm{TiO}_{2}$ film on $\operatorname{Pt}(111)$ (Figure 1a, spectrum ii).

When the O1s region of the XP spectrum is investigated for the same series of experiments, it is seen that the thick $\mathrm{TiO}_{2}$ film on $\mathrm{Pt}(111)$ (Figure $1 \mathrm{~b}$, spectrum ii) reveals an $\mathrm{O} 1 \mathrm{~s}$ signal at $530.2 \mathrm{eV}$, consistent with an almost fully oxidized $\mathrm{TiO}_{2}$ film. ${ }^{9} \mathrm{Ba}$ dosing at RT (Figure 1b, spectrum iii) gives rise to the broadening of the O1s signal at $530.2 \mathrm{eV}$ most likely due to the partial oxidation of $\mathrm{Ba}$ to form $\mathrm{BaO} / \mathrm{BaO}_{2} / \mathrm{BaO}_{x}$ (the characteristic O1s signal for $\mathrm{BaO}$ appears at $528.5-529.5 \mathrm{eV}$, and the signal for $\mathrm{BaO}_{2}$ appears at a $1.8-2.5 \mathrm{eV}$ higher binding energy $\left.(\mathrm{BE})^{10,11}\right)$. An additional shoulder which becomes visible at $531.6 \mathrm{eV}$ in Figure $1 \mathrm{~b}$, spectrum $\mathrm{iii}$, can be ascribed to perovskite-type surface species $\left(\mathrm{BaTiO}_{3} / \mathrm{Ba}_{2} \mathrm{TiO}_{4} / \mathrm{Ba}_{x} \mathrm{Ti}_{y} \mathrm{O}_{z}\right){ }^{12}$ It is worth mentioning that $\mathrm{Ba}_{2} \mathrm{TiO}_{4}$ (barium orthotitanate) is a metastable phase that has been reported ${ }^{13}$ to precede $\mathrm{BaTiO}_{3}$ formation during the reaction between $\mathrm{BaO} / \mathrm{BaCO}_{3}$ and $\mathrm{TiO}_{2}$ at elevated temperatures. Oxidation of this $\mathrm{Ba}$ overlayer with $\mathrm{O}_{2}$ followed by an additional Ba evaporation and oxidation step at $523 \mathrm{~K}$ (Figure 1b, spectrum iv) accentuates and shifts the shoulder to $532.1 \mathrm{eV}$ suggesting an increase in the surface population of perovskite-like surface domains. After oxidation at $973 \mathrm{~K}$ (Figure 1b, spectrum v), the Ti2p signal reveals a pronounced increase and the shoulder at $532.1 \mathrm{eV}$ almost completely disappears, yielding an O1s spectrum that is quite similar to that of $\mathrm{TiO}_{2} / \mathrm{Pt}(111)$ (Figure $1 \mathrm{~b}$, spectrum ii).

$\mathrm{Ba} 3 \mathrm{~d}_{5 / 2}$ spectra given in Figure $1 \mathrm{c}$ are in good agreement with the observations discussed above. After the initial deposition of the $\mathrm{Ba}$ on $\mathrm{TiO}_{2} / \mathrm{Pt}(111)$ at RT (Figure 1c, spectrum iii), the $\mathrm{Ba} \mathrm{d}_{5 / 2}$ signal at $780.6 \mathrm{eV}$ is detected. Although the $\mathrm{BE}$ of this feature does not significantly shift after oxidation-Ba depositionoxidation procedure (Figure 1c, spectrum iv), its intensity increases in a pronounced manner which is attributed to the additional dose of $\mathrm{Ba}$ and an improved forward photoelectron scattering due to the increasing wetting/surface dispersion of the $\mathrm{BaO}_{x} /$ $\mathrm{Ba}_{x} \mathrm{Ti}_{y} \mathrm{O}_{z}$ domains. In contrast, oxidation at $973 \mathrm{~K}$ prompts a significant attenuation of the Ba $3 \mathrm{~d}_{5 / 2}$ signal (Figure 1c, spectrum v).

In the light of the observations presented above, it can be argued that metallic $\mathrm{Ba}$ adsorption on the $\mathrm{TiO}_{2} / \mathrm{Pt}(111)$ surface at $\mathrm{RT}$ in vacuum induces a strong interaction between surface $\mathrm{O}^{2-}$ sites and $\mathrm{Ba}$ atoms, oxidizing the $\mathrm{Ba}^{0}$ species while reducing the $\mathrm{Ti}^{4+}$ sites. Oxidation of this surface with $\mathrm{O}_{2}$ at an intermediate temperature such as $523 \mathrm{~K}$ triggers the formation of $\mathrm{BaO}_{x}$ as well as perovskite-type mixed oxide domains such as $\mathrm{BaTiO}_{3}, \mathrm{Ba}_{2} \mathrm{TiO}_{4}$, and possibly their defective forms $\left(\mathrm{Ba}_{x} \mathrm{Ti}_{y} \mathrm{O}_{z}\right)$. Decrease in the Ti2p signal after $\mathrm{Ba}$ deposition at RT and oxidation at $523 \mathrm{~K}$ in comparison to the clean $\mathrm{TiO}_{2} / \mathrm{Pt}(111)$ surface is in agreement with the fact that the titania layer resides below the $\mathrm{BaO}_{x} /$ $\mathrm{Ba}_{x} \mathrm{Ti}_{y} \mathrm{O}_{z}$ overlayer under these conditions. Meanwhile, increasing the oxidation temperature to $973 \mathrm{~K}$ results in a drastic change in the surface composition. This is evident from the considerable decrease in the $\mathrm{Ba} 3 \mathrm{~d}_{5 / 2}$ signal intensity, concomitant to a significant rise in the Ti2p signal intensity. These observations can be explained by the segregation of the Ti sites to the topmost surface and the diffusion of $\mathrm{BaO}_{x} / \mathrm{Ba}_{x} \mathrm{Ti}_{y} \mathrm{O}_{z}$ domains beneath the $\mathrm{TiO}_{2}$ overlayer, giving rise to a $\mathrm{TiO}_{2}$-terminated surface.

The temperature-dependent structural changes on the $\mathrm{BaO}_{x} /$ $\mathrm{TiO}_{2} / \mathrm{Pt}(111)$ surface were also further investigated via LEED (Figure 2). Figure 2a presents the LEED image corresponding to a thick (ca. $26 \mathrm{MLE}$ ) $\mathrm{TiO}_{2}$ film grown on a clean $\mathrm{Pt}(111)$

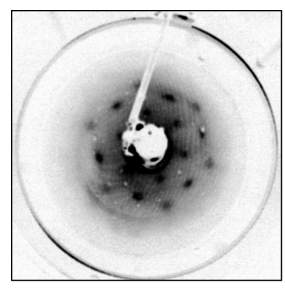

(a)

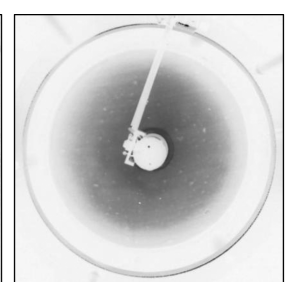

(b)

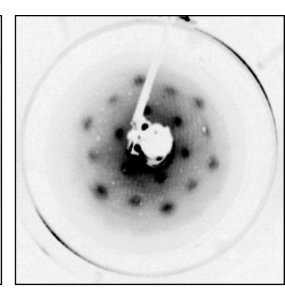

(c)
Figure 2. LEED images corresponding to (a) $(2 \times 2) \mathrm{TiO}_{2}(26 \mathrm{MLE}) /$ $\mathrm{Pt}(111)$, (b) $\mathrm{BaO}_{x}(<1 \mathrm{MLE}) / \mathrm{TiO}_{2}(26 \mathrm{MLE}) / \mathrm{Pt}(111)$, (c) a surface obtained by the oxidation of sample (b) in $\mathrm{O}_{2}\left(P_{\mathrm{O}_{2}}=5 \times 10^{-7}\right.$ Torr $)$ at $1073 \mathrm{~K}$. LEED patterns were recorded using electron energy values of 85,85 , and $105 \mathrm{eV}$, respectively.

substrate as described above. In spite of the significant thickness of the $\mathrm{TiO}_{2}$ overlayer, broad but clearly discernible LEED spots are apparent in Figure 2a, indicating the presence of a long-range ordering in the $\mathrm{TiO}_{2}$ film revealing a $(2 \times 2)$ structure. A similar $c(2 \times 2)$ reconstruction has also been observed on a rutile $\mathrm{TiO}_{2}(100)$ surface. ${ }^{14,15}$ Former reports in the literature demonstrated that $\mathrm{TiO}_{2}$ ultrathin films grown on $\mathrm{Pt}(111)$ can exhibit a variety of ordered structures. ${ }^{16,17}$ For instance, $\mathrm{TiO}_{2}$ ultrathin films grown on $\mathrm{Pt}(111)$ with a titania overlayer coverage of 0.8 ML present a LEED diffraction revealing zigzag-like $\mathrm{TiO}_{x}$ features which is also referred as the " $\mathrm{z}-\mathrm{TiO}_{x}$ " overlayer. ${ }^{16}$ This so-called z-overlayer was assigned to an incommensurate superstructure with respect to the $\mathrm{Pt}(111)$ substrate with a rectangular unit cell of about $(6.8 \pm 0.1) \times(8.6 \pm 0.1) \AA^{2} \cdot{ }^{17}$ Former STM studies in the literature also suggested that the $\mathrm{z}-\mathrm{TiO}_{x}$ structure was comprised of an $\mathrm{O}-\mathrm{Ti}$ bilayer, with an oxygen termination. ${ }^{16}$ Other ordered $\mathrm{TiO}_{2}$ overlayers on $\mathrm{Pt}(111)$ were also observed in the literature ${ }^{16}$ for a $\mathrm{TiO}_{2}$ overlayer coverage of 1.2 MLE. This latter ordered overlayer was called wagon-wheel-like or $\mathrm{w}-\mathrm{TiO}_{x}$ structure. ${ }^{16} \mathrm{~A}$ detailed analysis of this $\mathrm{w}-\mathrm{TiO}_{x} / \mathrm{Pt}(111)$ surface revealed that $\mathrm{w}-\mathrm{TiO}_{x}$ overlayer formed an ordered $(\sqrt{ } 43 \times$ $\sqrt{ } 43) \mathrm{R} 7.6^{\circ}$ structure with a unit vector of $18.2 \AA^{.16}$

The ordered overlayer in Figure 2a is lost when $\mathrm{Ba}(<1 \mathrm{MLE})$ is deposited on $\mathrm{TiO}_{2} / \mathrm{Pt}(111)$ and oxidized at $523 \mathrm{~K}$ in $\mathrm{O}_{2}$ (Figure $2 \mathrm{~b}$ ) suggesting that $\mathrm{BaO}_{x}-\mathrm{Ba}_{x} \mathrm{Ti}_{y} \mathrm{O}_{z}$ overlayer on $\mathrm{TiO}_{2} /$ $\mathrm{Pt}(111)$ has an amorphous structure. Interestingly, oxidation of the $\mathrm{BaO}_{x}-\mathrm{Ba}_{x} \mathrm{Ti}_{y} \mathrm{O}_{z}$ overlayer on $\mathrm{TiO}_{2} / \mathrm{Pt}(111)$ at $1073 \mathrm{~K}^{\text {in } \mathrm{O}_{2}}$ regenerates the $(2 \times 2)$ LEED pattern that is obtained for the clean $\mathrm{TiO}_{2} / \mathrm{Pt}(111)$ surface. These LEED results are in agreement with the conclusion that oxidation of the $\mathrm{BaO}_{x} / \mathrm{Ba}_{x} \mathrm{Ti}_{y} \mathrm{O}_{z}$ overlayers on $\mathrm{TiO}_{2} / \mathrm{Pt}(111)$ gives rise to the diffusion of the $\mathrm{BaO}_{x} / \mathrm{Ba}_{x} \mathrm{Ti}_{y} \mathrm{O}_{z}$ domains into the $\mathrm{TiO}_{2}$ matrix leading to the segregation of Ti sites on the surface and the formation of a $\mathrm{TiO}_{2}-$ terminated overlayer. Reconstruction of perovskite surfaces and the formation of $\mathrm{TiO}_{2} / \mathrm{TiO}$-terminated surface structures at elevated temperatures have also been reported for $\mathrm{SrTiO}_{3}(001)^{18,19}$ and $\mathrm{SrTiO}_{3}(111)^{20}$ surfaces. $\mathrm{TiO}_{2}$-terminated surfaces have been observed for the $(2 \times 1)$ reconstruction ${ }^{18}$ and the $c(4 \times 2)$ reconstruction of $\mathrm{SrTiO}_{3}(001)$ at elevated temperatures, ${ }^{19}$ and a $\mathrm{TiO}(111)-(2 \times 2)$ terminated reconstructed surface was observed on $\mathrm{SrTiO}_{3}(111){ }^{20}$

We have investigated these thermally induced structural changes for a variety of temperatures in which we have monitored the $\mathrm{Ba} / \mathrm{Ti}$ surface atomic ratio via XPS after oxidation steps carried out at temperatures ranging from 300 to $1073 \mathrm{~K}$. In these experiments $\mathrm{Ba}$ with an estimated coverage of $<1$ MLE was 


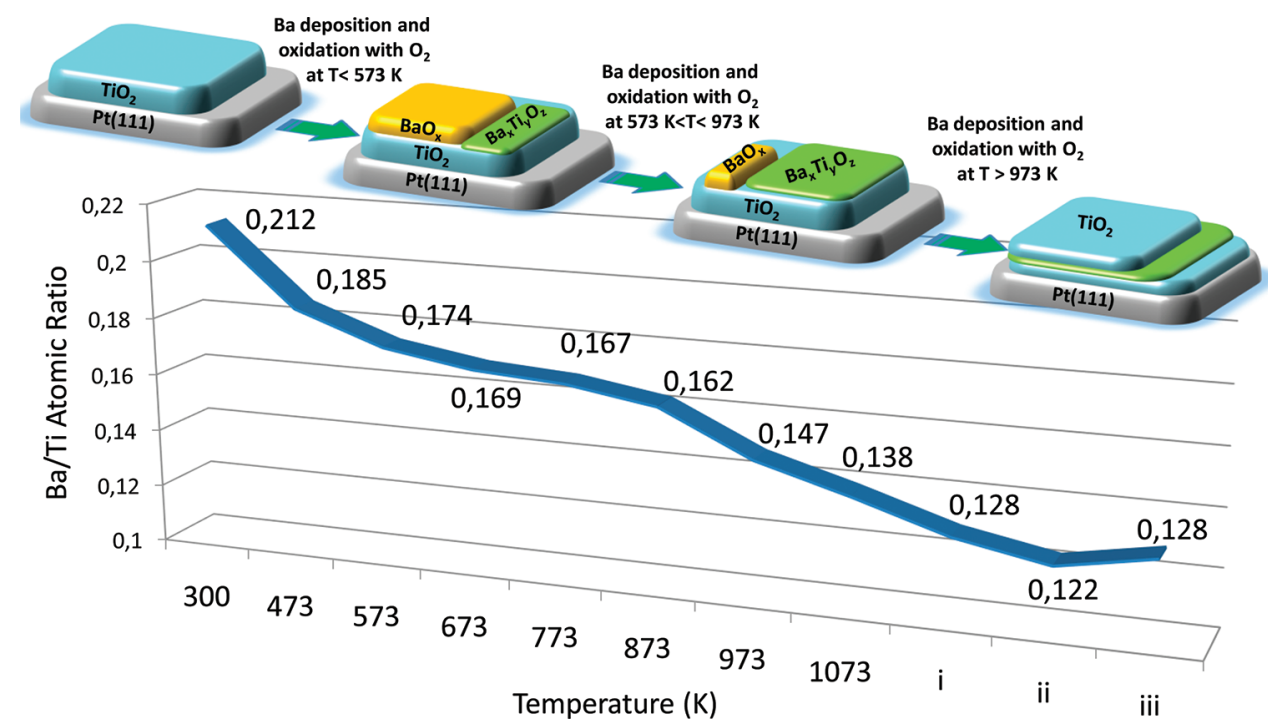

Figure 3. $\mathrm{Ba} / \mathrm{Ti}$ surface atomic ratio values obtained from the XPS data for a $\mathrm{BaO}_{x}(<1 \mathrm{MLE}) / \mathrm{TiO}_{2}(26 \mathrm{MLE}) / \mathrm{Pt}(111)$ surface after various oxidation and thermal aging steps at various temperatures (see text for details).

deposited on $\mathrm{TiO}_{2}(26 \mathrm{MLE}) / \mathrm{Pt}(111)$ surface. As summarized in Figure 3, Ba/Ti surface atomic ratio displays a monotonic decrease with increasing oxidation temperatures. Note that the oxidation steps were typically performed with an $\mathrm{O}_{2}$ partial pressure of $5 \times 10^{-7}$ Torr and for durations of $20 \mathrm{~min}$. Sample $\mathrm{i}$ in Figure 3 was treated with $\mathrm{O}_{2}$ at $1073 \mathrm{~K}$ for $30 \mathrm{~min}$. Sample ii was obtained by annealing sample $\mathrm{i}$ in vacuum at $1073 \mathrm{~K}$ for $30 \mathrm{~min}$, and sample iii was obtained by dosing $1 \times 10^{-7}$ Torr $\mathrm{NO}_{2}$ (a more aggressive oxidizing agent than $\mathrm{O}_{2}$ ) on sample ii at a temperature of $300 \mathrm{~K}$ for $30 \mathrm{~min}$ followed by annealing at $1073 \mathrm{~K}$ (to further oxidize the surface and desorb the residual $\mathrm{NO}_{x}$ species). Figure 3 reveals that, even after the oxidation steps at relatively low temperatures $(T<573 \mathrm{~K})$, a rather sharp decrease in the $\mathrm{Ba} / \mathrm{Ti}$ surface atomic ratio is visible, indicating that the $\mathrm{Ba}$ diffusion into the $\mathrm{TiO}_{2}$ matrix has a rather small activation barrier and is likely to occur even at relatively low temperatures. Note that the $\mathrm{Ba} / \mathrm{Ti}$ surface atomic ratio variation under these conditions may partly be ascribed to the agglomeration of the $\mathrm{BaO}$ domains and sintering; however, observed changes in the $\mathrm{O} 1 \mathrm{~s}$ region in XPS definitely indicate the presence of additional surface phenomena such as the formation of perovskite-type species due to $\mathrm{BaO}$ diffusion and reaction with the $\mathrm{TiO}_{2}$ matrix. Under these low-temperature oxidation conditions, the surface is dominated with $\mathrm{BaO}_{x}$ species with a smaller contribution from $\mathrm{Ba}_{x} \mathrm{Ti}_{y} \mathrm{O}_{z}$ domains. Figure 3 also reveals that the $\mathrm{Ba} / \mathrm{Ti}$ surface atomic ratio is observed to stay fairly stable within a broad band of intermediate temperatures (i.e., 573-873 K). Within this temperature window, current XPS results indicate that the surface contains a larger contribution from perovskite-type species $\left(\mathrm{Ba}_{x} \mathrm{Ti}_{y} \mathrm{O}_{z}\right)$. At oxidation temperatures above $873 \mathrm{~K}$, a steep decline in the $\mathrm{Ba} / \mathrm{Ti}$ surface atomic ratio is visible suggesting a fast and an efficient diffusion of $\mathrm{Ba}$ sites into the underlying $\mathrm{TiO}_{2}$ framework. It is also apparent in Figure 3 that, after extended oxidation and/or annealing steps performed at $1073 \mathrm{~K}, \mathrm{Ba} / \mathrm{Ti}$ surface atomic ratio reaches a rather steady value where the surface is characterized by LEED pattern presented in Figure $2 c$ and its XPS analysis reveals similar characteristics to the topmost XPS spectra in Figure 1.

Chemical reactivity of the $\mathrm{BaO}_{x} / \mathrm{Ba}_{x} \mathrm{Ti}_{y} \mathrm{O}_{z}$ overlayers on $\mathrm{TiO}_{2} / \mathrm{Pt}(111)$ were also studied toward various ubiquitous adsorbates in heterogeneous catalysis (i.e., $\mathrm{NO}_{2}$ and $\mathrm{CO}_{2}$ ) which are relevant to numerous catalytic systems including (but not limited to) $\mathrm{NO}_{x}$-storage reduction systems. ${ }^{21-26}$ In order to achieve this, adsorption experiments were performed by saturating the surfaces with either $\mathrm{NO}_{2}$ or $\mathrm{CO}_{2}$ at RT $\left(P_{\mathrm{NO}_{2}}=1 \times 10^{-7}\right.$ Torr for $30 \mathrm{~min}$ at RT and $P_{\mathrm{CO}_{2}}=5 \times 10^{-7}$ Torr for 5 min at RT) and then monitoring the desorption profiles at elevated temperatures via TPD. Figure 4a depicts a TPD profile obtained after $\mathrm{NO}_{2}$ saturation of $\mathrm{BaO}_{x}(6 \mathrm{MLE}) / \mathrm{TiO}_{2}(26 \mathrm{MLE}) / \mathrm{Pt}(111)$ surface at RT. On the basis of the current XPS results, this surface is dominated by $\mathrm{BaO}_{x}$ domains with a smaller contribution from $\mathrm{Ba}_{x} \mathrm{Ti}_{y} \mathrm{O}_{z}$ domains. TPD spectrum given in Figure $4 \mathrm{a}$, spectrum $\mathrm{i}$, corresponding to $m / z=30$, clearly indicates that this surface can efficiently store $\mathrm{NO}_{2}$ most likely in the form of nitrates resulting in a desorption maximum at $635 \mathrm{~K}$ that is consistent with the strongly bound ionic $\mathrm{NO}_{3}{ }^{-} / \mathrm{NO}_{2}{ }^{-}$species adsorbed on $\mathrm{BaO}_{x}{ }^{25}$ and $\mathrm{Ba}_{x} \mathrm{Ti}_{y} \mathrm{O}_{z}$ domains. ${ }^{28}$ It should be mentioned that, although $\mathrm{NO}_{x}$ storage capacity of supported $\mathrm{BaO}$ surfaces are typically higher than that of $\mathrm{BaTiO}_{3}, \mathrm{BaTiO}_{3}$ surfaces can also store appreciable amount of $\mathrm{NO}_{2}$ or $\mathrm{CO}_{2}$ in the form of nitrates/ nitrites or carbonates, respectively. This might be partly ascribed to the $\mathrm{BaO}$ termination of the $\mathrm{BaTiO}_{3}(100)$ surface. ${ }^{29}$ It is also worth mentioning that no oxygen $(\mathrm{m} / z=32)$ evolution was detected in this TPD experiment suggesting that the oxygen atoms produced during the decomposition of nitrates/nitrites are either dissolved in the subsurface or take part in the oxidation of $\mathrm{BaO}$ to $\mathrm{BaO}_{2}$ as commonly observed in the case of $\mathrm{NO}_{2}$ desorption from $\mathrm{BaO}$ overlayers. ${ }^{8,23,24}$ TPD profile given in Figure $4 a$, spectrum ii $(m / z=30)$ was obtained by saturating the surface given in spectrum i with $\mathrm{NO}_{2}$ after the first TPD run (in other words, spectrum ii corresponds to the second successive $\mathrm{NO}_{2}-\mathrm{TPD}$ of the freshly prepared surface). It is evident from Figure 4a, spectrum ii that the $\mathrm{NO}_{x}$ uptake capacity of the surface is almost completely lost after the first TPD run due to the formation of $\mathrm{TiO}_{2}$-terminated surface and the diffusion of surface $\mathrm{Ba}$ sites into the subsurface. In order to demonstrate the relatively small $\mathrm{NO}_{2}$ adsorption capacity of $\mathrm{TiO}_{2}$-terminated surfaces compared to that of $\mathrm{BaO}_{x}$ terminated surfaces, we have also performed a control experiment in which $\mathrm{NO}_{2}$ was adsorbed on 

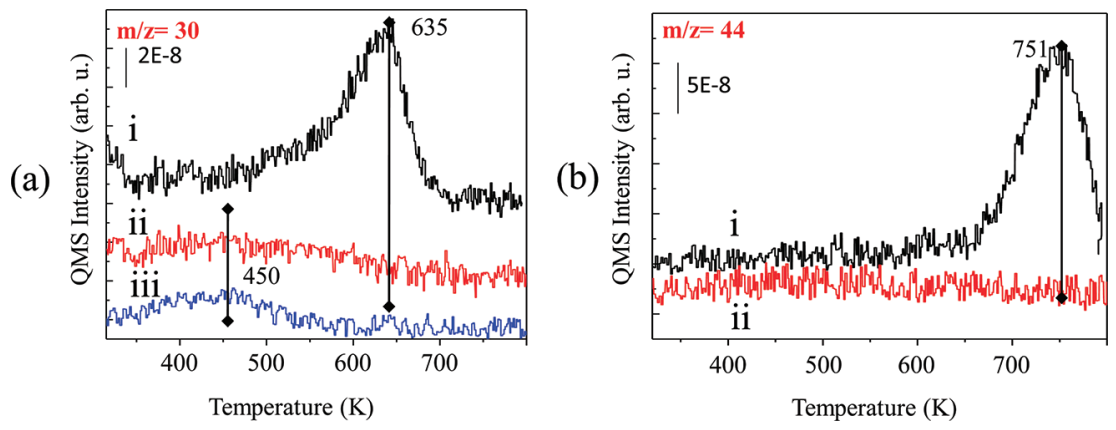

Figure 4. (a) $m / z=30$ desorption channel in the TPD profiles for $\mathrm{NO}_{2}$ adsorption $\left(P_{\mathrm{NO}_{2}}=1 \times 10^{-7}\right.$ Torr for $30 \mathrm{~min}$ at $\left.\mathrm{RT}\right)$ on fresh $\mathrm{BaO}{ }_{x}(6 \mathrm{MLE}) /$ $\mathrm{TiO}_{2}(26 \mathrm{MLE}) / \mathrm{Pt}(111)$ surface (spectrum i), $\mathrm{BaO}_{x}(6 \mathrm{MLE}) / \mathrm{TiO}_{2}(26 \mathrm{MLE}) / \mathrm{Pt}(111)$ surface pretreated at $973 \mathrm{~K}$ (spectrum ii), and fresh $\mathrm{TiO}{ }_{2}$ $(26 \mathrm{MLE}) / \mathrm{Pt}(111)$ surface (spectrum iii). (b) $\mathrm{m} / z=44$ desorption channels in the TPD profiles for $\mathrm{CO}_{2}$ adsorption $\left(P_{\mathrm{CO}_{2}}=5 \times 10^{-7} \mathrm{Torr}\right.$ for $5 \mathrm{~min}$ at RT) on: fresh $\mathrm{BaO}_{x}(6 \mathrm{MLE}) / \mathrm{TiO}_{2}(26 \mathrm{MLE}) / \mathrm{Pt}(111)$ surface (spectrum i), $\mathrm{BaO}_{x}(6 \mathrm{MLE}) / \mathrm{TiO}_{2}(26 \mathrm{MLE}) / \mathrm{Pt}(111)$ surface pretreated at $973 \mathrm{~K}$ (spectrum ii).

a $\mathrm{TiO}_{2}(26 \mathrm{MLE}) / \mathrm{Pt}(111)$ surface at $\mathrm{RT}$ (Figure 4a, spectrum iii). In this control experiment, a characteristically weak $\mathrm{m} / \mathrm{z}=30$ desorption signal was detected with a significantly lower desorption maximum within $400-450 \mathrm{~K}$ pointing to the fact that the saturation coverage and the adsorption strength of adsorbed $\mathrm{NO}_{x}$ species on a $\mathrm{TiO}_{2}$-terminated $\mathrm{TiO}_{2} / \mathrm{Pt}(111)$ surface at $\mathrm{RT}$ is much smaller compared to that of $\mathrm{BaO}_{x} / \mathrm{TiO}_{2} / \mathrm{Pt}(111)$ (Figure 4a, spectrum i) and $\mathrm{BaO}_{x} / \mathrm{Pt}(111)^{8}$ surfaces.

This observation is also in perfect agreement with the additional TPD experiments performed by saturating the surfaces given in Figure 4a, spectra $\mathrm{i}$ and ii with $\mathrm{CO}_{2}$ at RT (Figure $4 b$ ). Figure $4 \mathrm{~b}$, spectrum $\mathrm{i}$ reveals a strong $\mathrm{m} / z=44$ desorption signal at $751 \mathrm{~K}$, associated with the decomposition of strongly bound ionic carbonate-like surface species. It is also crucial to emphasize that the $\mathrm{CO}_{2}$ uptake of the surface given in Figure $4 \mathrm{~b}$, spectrum $\mathrm{i}$ seems to be completely suppressed after annealing at $973 \mathrm{~K}$ (Figure $4 \mathrm{~b}$, spectrum ii). The reason for the suppression of $\mathrm{CO}_{2}$ uptake is also associated with the formation of a Ti-enriched surface overlayer on a thermally aged $\mathrm{BaO}_{x} / \mathrm{TiO}_{2} / \mathrm{Pt}(111)$ system.

\section{CONCLUSIONS}

Current results shed light on the fundamental aspects of the thermally induced surface structural transformations of alkaline earth oxide/transition metal oxide interfaces and provide valuable insights regarding their catalytic deactivation pathways. By utilizing the $\mathrm{BaO}_{x} / \mathrm{TiO}_{2} / \mathrm{Pt}(111)$ model system, it was demonstrated that perovskite-type surface species (i.e., $\mathrm{BaTiO}_{3} / \mathrm{Ba}_{2} \mathrm{TiO}_{4} /$ $\mathrm{Ba}_{x} \mathrm{Ti}_{y} \mathrm{O}_{z}$ ) form even at temperatures as low as $523 \mathrm{~K}$, concomitant to the diffusion of $\mathrm{BaO}_{x} / \mathrm{Ba}_{x} \mathrm{Ti}_{y} \mathrm{O}_{z}$ species into the underlying $\mathrm{TiO}_{2}$ framework. Diffusion of Ba-containing species into the $\mathrm{TiO}_{2}$ framework is further facilitated at $T>873 \mathrm{~K}$. These surface phenomena result in a $\mathrm{TiO}_{2}$-terminated surface which is almost completely deficient of Ba-containing domains exposed on the surface. The surface segregation of $\mathrm{TiO}_{2}$ species yields a surface structure that is incapable of performing some of the vital catalytic functions of the investigated alkaline earth oxide/transition metal oxide interface, such as $\mathrm{NO}_{2} / \mathrm{CO}_{2}$ adsorption and storage. Currently observed surface phenomena unveil a general behavior that has direct potential implications in high temperature superconductivity, solid oxide fuel cells (SOFC), sensors, and electronic device applications. Further surface scientific investigations are required in order to elucidate and control such surface/ subsurface diffusion phenomena and diffusion kinetics and to design advanced structural promoters that can act as diffusion barriers ${ }^{30,31}$ in mixed oxide interfacial systems.

\section{AUTHOR INFORMATION}

\section{Corresponding Author}

*E-mail: ozensoy@fen.bilkent.edu.tr.

\section{ACKNOWLEDGMENT}

Authors acknowledge the financial support from TUBITAK (Grant No. 107Y115) and RFBR (No. 09-03-91225-CT_a and No. 10-03-00596-a). E.O. also acknowledges support from Turkish Academy of Sciences for the "Outstanding Young Investigator" Grant. Authors also gratefully acknowledge Prof. Mehmet Erbudak (ETH, Zurich) for his help with the LEED and XPS measurements and for fruitful discussions.

\section{REFERENCES}

(1) Mathews, S.; Ramesh, R.; Venkatesan, T.; Benedetto, J. Science 1997, 276, 238.

(2) Takata, T.; Domen, K. J. Phys. Chem. C 2009, 113, 19386.

(3) Raj, E. S.; Pratt, K. F. E.; Skinner, S. J.; Parkin, I. P.; Kilner, J. A. Chem. Mater. 2006, 18, 3351.

(4) Larbalestier, D.; Gurevich, A.; Feldmann, D. M.; Polyanskii, A. Nature 2001, 414, 368.

(5) Mamak, M.; Metraux, G. S.; Petrov, S.; Coombs, N.; Ozin, G. A.; Green, M. A. J. Am. Chem. Soc. 2003, 125, 5161.

(6) Alexander, M. R.; Thompson, G. E.; Zhou, X.; Beamson, G.; Fairley, N. Surf. Interface Anal. 2002, 34, 485.

(7) Tanuma, S.; Powell, C. J.; Penn, D. N. Surf. Interface Anal. 1994, 21, 165 .

(8) Vovk, I. E., Emmez, E., Erbudak, M., Bukhtiyarov, V. I., Ozensoy, E. submitted.

(9) Oku, M.; Wagatsuma, K.; Kohiki, S. Phys. Chem. Chem. Phys. 1999, 1, 5327.

(10) Dissanayake, D.; Kharas, K. C. C.; Lunsford, J. H.; Rosynek, M. P. J. Catal. 1993, 139, 652.

(11) Desikusumastuti, A.; Happel, M.; Dumbuya, K.; Staudt, T.; Laurin, M.; Gottfried, J. M.; Steinruck, H. P.; Libuda, J. J. Phys. Chem. C 2008, 112, 6477.

(12) Förster, S.; Widdra, W. Surf. Sci. 2010, 604, 2163.

(13) Lotnyk, A.; Senz, S.; Hesse, D. Solid State Ionics 2006, 177, 429.

(14) Warschkow, O.; Wang, Y.; Subramanian, A.; Asta, M.; Marks, L. D. Phys. Rev. Lett. 2008, 100, 086102.

(15) Wang, Y.; Warschkow, O.; Marks, L. D. Surf. Sci. 2007, $601,63$. 
(16) Sedona, F.; Rizzi, G. A.; Agnoli, S.; Llabres i Xamena, F. X.; Papageorgiou, A.; Ostermann, D.; Sambi, M.; Finetti, P.; Schierbaum, K.; Granozzi, G. J. Phys. Chem. B 2005, 109, 24411.

(17) Barcaro, G.; Sedona, F.; Fortunelli, A.; Granozzi, G. J. Phys. Chem. C 2007, 111, 6095.

(18) Erdman, N.; Poeppelmeier, K. R; Asta, M.; Warschkow, O.; Ellis, D. E.; Marks, L. D. Nature 2002, 419, 55.

(19) Erdman, N.; Warschkow, O.; Asta, M.; Poeppelmeier, K. R.; Ellis, D. E.; Marks, L. D. J. Am. Chem. Soc. 2003, 125, 10050.

(20) Russell, B. C.; Castell, M. R. J. Phys. Chem. C 2008, 112, 6538.

(21) Epling, W. S.; Campbell, L. E.; Yezerets, A.; Currier, N. W.; Parks, J. E. Catal. Rev. 2004, 46, 163.

(22) Roy, S.; Baiker, A. Chem. Rev. 2009, 109, 4054.

(23) Ozensoy, E.; Peden, C. H. F.; Szanyi, J. J. Phys. Chem. B 2006, 110,17001 .

(24) Ozensoy, E.; Peden, C. H. F.; Szanyi, J. J. Phys. Chem. B 2006, $110,17009$.

(25) Ozensoy, E.; Peden, C. H. F.; Szanyi, J. J. Catal. 2006, 243, 149.

(26) Andonova, S. M.; Șentürk, G. S.; Kayhan, E.; Ozensoy, E. J. Phys. Chem. C 2009, 113, 11014.

(27) Andonova, S. M.; Șentürk, G. S.; Ozensoy, E. J. Phys. Chem. C 2010, 114, 17003.

(28) Hodjati, S.; Vaezzadeh, K.; Petit, C.; Pitchon, V.; Kiennemann, A. Appl. Catal., B 2000, 26, 5.

(29) Berlich, A.; Strauss, H.; Langheinrich, C.; Chassé, A.; Morgner, H. Surf. Sci. 2011, 605, 158.

(30) Takahashi, N.; Suda, A.; Hachisuka, I.; Sugiura, M.; Sobukawa, H.; Shinjoh, H. Appl. Catal., B 2007, 72, 187.

(31) Imagawa, H.; Tanaka, T.; Takahashi, N.; Matsunaga, S.; Suda, A.; Shinjoh, H. J. Catal. 2007, 251, 315. 